\title{
CORRELATION BETWEEN THE SYSTEM OF REMUNERATION OF POLICE OFFICERS AND THEIR PROFESSIONAL PERFORMANCE: FOREIGN EXPERIENCE
}

\author{
Artem Shevchyshen ${ }^{1}$ \\ National Police of Ukraine, Ukraine \\ Olha Kryshevych ${ }^{2}$, Olena Lepei ${ }^{3}$ \\ National Academy of Internal Affairs, Ukraine
}

\begin{abstract}
The aim of the article is to analyse the foreign experience of correlation between the system of remuneration of police officers and their professional performance, to identify the features of fixing the rate and types of police officers' remuneration in some foreign countries, and to ascertain the relationship between such remuneration and their professional performance. The subject of the study is the foreign experience of correlation between the system of police officer remuneration and professional performance. Methodology. The research is based on a comparison of the system of police officer remuneration in Ukraine and in foreign countries. Based on the analysis of the features of police officer remuneration in Canada and the United Kingdom, the advantages and disadvantages of the different conditions and procedure of remuneration are determined. Based on a comparative legal study of certain provisions of Ukrainian legislation, the possibilities and limits of implementation of positive foreign experience in this sphere are determined. The results of the study revealed that encouraging employees according to the professional performance enables to solve problems connected with the increase of efficiency of the law-enforcement system in Ukraine. Therefore, nowadays, the development of clear criteria for assessing the professional performance of law enforcement officials, construction of an effective system of material incentives based on professional performance are a priority task. Therefore, in the course of further reform of the police, such as improving social policy, the issue of forming new principles and methodology for the encouragement of employees objectively considering their professional performance is of particular importance. The use of foreign experience in solving such problems can be a positive example for domestic public administration bodies in the implementation of social reforms in law enforcement structures. Practical implications. Positive experience of correlation between the system of remuneration of police officers and their professional performance confirms that the system of indicators should evaluate comprehensively the activities of employees, units, and the National Police System as a whole, include the full range of indicators necessary for evaluation, exclude duplicate or secondary indicators, consider the priority of the tasks performed, clearly reflect the degree of achievement at all levels of the system, and be based on the potentials of budget financing. The system of supplementary payments must be based on a finite number of professional performance indicators. Moreover, it is important to meet such criterion as objectivity, adequacy of types, and rate of supplementary payments. In addition, fixing supplementary payments, based on performance efficiency indicators, should reflect the danger, importance for the state and society and specificity of the tasks performed, as well as the priority exercised by the police. In addition, the number of indicators linked to supplementary payments should be optimal, otherwise, in case of an overly-specified system with a large number of indicators reflecting relatively small functions, there is a risk of shifting from solving key problems, as well as compensation for the decline in the quality of core duty performance by a large number of less significant functions. Relevance/originality. Comparative analysis of the correlation between the system of remuneration of police officers and their professional performance is the basis for the development of the most progressive directions to improve domestic legislation.
\end{abstract}

Key words: law-enforcement bodies, police, remuneration, professional performance.

JEL Classification: P17

\footnotetext{
Corresponding author:

${ }^{1}$ Division of Central Investigation Department, National Police of Ukraine.

${ }^{2}$ Department of Criminal Law, National Academy of Internal Affairs.

${ }^{3}$ Department of Criminal Procedure, National Academy of Internal Affairs.

E-mail: elena031077@gmail.com
} 


\section{The relevance of the topic}

At the end of the XX - beginning of the XXI century, social protection of citizens has become a priority area of the social policy of any civilized state. Today, for many countries, one of the main objectives of social policy is to support the stability of the population's income, high-quality medical care, development of the social insurance system, provision of equal access to education services and decent retirement pension. In developed countries, providing social protection for their citizens is an essential part of the national economy. Therefore, the existence of an effective system of social guarantees both leads to an increase in the welfare of the population and contributes to economic growth and stabilization of the political and social situation in the state.

A special role in the social policy of any state belongs to ensuring the social protection of public officials, including police officials.

Considering maintenance and encouragement of police, the general secretary of the UK Police Federation Jeff Mosley emphasizes indicatively that either society wants to have a police service that it deserves and is ready to pay for it, or it does not. In any case, it should be ready to make a decision (Jenkins, 1999).

The scope of tasks related to police reform is quite broad. One of the key areas is to increase the effectiveness of the entire law-enforcement system. The solution to this issue affects not only the capacity and ability of the police to perform professional functions at a decent level but also to ensure that their status is consistent with the contest and needs of modern society. Today, it is evident that the recent reform has yielded some results. However, in order to make the law-enforcement system effective, the measures taken are not enough. Much more needs to be done to reduce crime, optimize budget expenditures for law enforcement bodies, including police forces, to reduce corruption, change the attitude of citizens towards this structure, and to increase the prestige of service in law enforcement bodies.

In the course of the police transformation, one of the key areas is to form a new system of social guarantees provided to employees and members of their families. Meanwhile, the adoption of a package of documents on social guarantees is the first step towards improving the system of social protection of employees. The effective implementation of these plans and the construction of the police model, which is consistent with the state's strategic objectives and requirements of modern society, ensure the successful modernization.

Definitely, this important and complex process requires proper scientific support. In this regard, in terms of further reformation of law enforcement bodies, in particular, the police, the study of the experience of foreign countries is relevant because it enables to expand the totality of existing ideas on improving the law- enforcement system, social policies on employees and their family members, to find constructive decisions.

The aim of the article is to analyse the foreign experience of correlation between the system of remuneration of police officers and their professional performance, to identify the features of fixing the rate and types of remuneration of police officers in some foreign countries, and to ascertain the relationship between such remuneration and their professional performance.

\section{The main material}

The enactment of the 2015 social guarantee package within the large-scale reform of the law enforcement bodies was the first step towards improving the system of social protection for police officers.

In particular, these include the Law of Ukraine "On the National Police" ((Pro Natsionalnu politsiiu)), the Law of Ukraine "On Retirement Pensions of Persons Discharged from Military Service, and Some Other Persons" (Pro pensiine zabezpechennia osib, zvilnenykh z viiskovoi sluzhby, ta deiakykh inshykh osib), Resolution of the Cabinet of Ministers of Ukraine "On Approval of the Regulation on the National Police" (Pro zatverdzhennia Polozhennia pro Natsionalnu politsiiu), Resolution of the Cabinet of Ministers of Ukraine "On Remuneration of Police Officers of the National Police (Pro hroshove zabezpechennia politseyskykh Natsionalnoi politsii), "On the procedure for calculating the years of service, appointment, and payment of pensions and remuneration to the commissioned officers, warrant officers, midshipmen, extended military servicemen and military service under the contract, persons of senior commanders and junior enlisted of the internal affairs bodies, police officers and their family members" (Pro poriadok obchyslennia vysluhy rokiv ...), Order of the Ministry of Internal Affairs of Ukraine "On approval of the procedure and conditions for payment of remuneration to provide police officers of the National Police and cadets of higher educational institutions of the Ministry of Internal Affairs with specific learning conditions" (Pro zatverdzhennia Poriadku ta umov vyplaty hroshvoho zabezpechennia politseyskym Natsionalnoi politsii...) etc.

Currently, the most important priority in the course of further reforms is an increase in the effectiveness of the social policy concerning the police officers. Nowadays, comparative analysis of social practices of various foreign countries is one of the most common methods of social policy research. Such an analysis enables:

- to gain experience for the future, identify the strengths and weaknesses of the social policy conducted, in particular, in law enforcement bodies;

- to evaluate tendencies, dynamics, results, and consequences of social renovations;

- to predict priority directions of development of social policy in law enforcement structures. 
It should be noted that in foreign countries, as a rule, police officers, in their legal status, are state or municipal officials and subject to the general legal regimes. However, according to their professional responsibilities and specifics of activity, police officers occupy a special place among other public officials. Consequently, it is reflected in the system of their social protection.

In recent years, many countries in the world have been undergoing social reforms in law enforcement bodies. Above all, these reforms are aimed at improving the effectiveness of law enforcement activities, reducing the scale of crime, increasing public confidence in such bodies. Each country implements these tasks in its own way considering its political, socio-economic situation, traditions, the experience of the previous stages of reformation.

Furthermore, there are common in most countries of the world key areas of social policy reform in law enforcement bodies. In particular, these include:

- change of staffing level;

- optimization or reduction of budgetary expenditures for maintaining the police; improvement of the system of remuneration;

- regulation of the system of supplementary payments to employees;

- development of new procedures of encouragement of professional activities;

- improvement of the system of social guarantees.

In the course of the reform of law enforcement bodies, Ukraine solves many similar problems, such as the formation of employee income and encouragement of professional activities. An important stage in the process of transformation is the development of a system of objective and clear performance indicators of law-enforcement activities and solving the problem of correlation between the system of remuneration of police officers and their professional performance, the rate of salary and encouragement of the work with professional performance.

Considering foreign experience, the absence of a single approach to the linkage between the rate of salary and encouragement of professional activities of police officers with their professional performance should be noted.

For example, salaries of most Canadian public officials, especially police officers, are not based on professional performance. Only about $4 \%$ of public officials receive salaries that depend on professional performance. The other $96 \%$ of salaries are set according to a fixed salary scale.

There are about 50 professional categories in Canada. Inside each category, there is an additional scale for determining the level of complexity of the work performed. Within each scale, annual step-by-step promotions are possible (up to five in each).

The salary increase for Canadian government employees is not related to the effectiveness of the work. However, for all employees, there are supplementary payments that consider the intensity and overtime work, as well as the increase in the cost of living. The rate of supplementary payments is determined during negotiations with trade unions. In other words, Canadian public officials, in particular, police officers, have two ways to raise salaries without changing jobs:

- grow on the scale of remuneration applicable to the relevant professional category;

- get an annual supplementary payment related to the rise in the cost of living.

It should be noted that although the level of remuneration of police officers in Canada is not based on the professional performance of their work, their salaries are generally higher than the remuneration of other categories of employees in the public sector. In other words, firstly, the level of police officer remuneration reflects the specifics of law enforcement activities related to the fulfilment of certain functions of the state, as well as increased physical and psychological stresses, the risk to the lives of employees and their families.

According to statistical data, the average salary of police officers is above the salary level of other categories of employees in the budget sphere.

For example, the average salary of a police officer in Ottawa is $35.67 \mathrm{CAD}$ per hour, while the average salary of social workers is $27.87 \mathrm{CAD}$ or almost $30 \%$ lower; in Toronto, the average salary of social workers is 17\% lower: from $36.47 \mathrm{CAD}$ for police officers and 31.19 CAD for social workers. However, in some provinces, such as Alberta, the average and maximum level of salaries for police officers are lower than for other categories of employees in the public sector (Official website of the Royal Canadian Equestrian Police).

Moreover, for the police of Canada, a sharp increase in salaries is characteristic after several years of service. For example, immediately after successful completion of training at police schools, the annual salary of the constable is $49,680 \mathrm{CAD}$ per year. During 36 months of service, the annual salary gradually increases by more than 1.5 times, up to $80,498 \mathrm{CAD}$.

The salary of senior management personnel of the Canadian Civil Service is based on professional performance. For each of the five degrees in this particular professional category, the government of Canada sets the basic pay rate, and then the salary increases depending on the performance during the calendar year. Supplementary payment for the performance is divided into two equal parts. One part is added to the permanent supplementary payment, which operates in relation to the rate of the salary. The other part is not guaranteed, because each year it can be paid or not depending on professional performance. Every year, the senior manager and his/her supervisor conclude a contract regarding the effectiveness of professional activities. The contract defines the expected results for the coming year; however, rarely these contracts are expressed in figures. Generally, 
they are of a "qualitative" nature, for example, the task is to increase the level of training, develop a new policy in dealing with a particular issue or administrative regulation, and even put personal goals concerning the individual style of leadership (in some cases it is a mandatory requirement). At the end of the calendar year, the manager is interviewed by his/her supervisor. The evaluation can be unsatisfactory, satisfactory, good, and excellent. Then the rate of supplementary payment to the salary is calculated on the basis of a simple formula: the higher the score, the higher the percentage of supplementary payment. Nevertheless, for each level, there is a limit on the rate of maximum supplementary payments.

However, an opposite approach can be considered. In the United Kingdom, in 1984, a system of remuneration for public officials was introduced, based on the assessment of the effectiveness of their work on the results of the performance certification. Initially experimental, this system became an obligatory component of UK public officials' remuneration policy. Since 1995, the incentive system for remuneration has been improved and expanded.

In recent years, labour encouragement is one of the most important principles of the system of material support for British public officials. Several normative legal acts regulate indicators of encouragement for employees of executive power. In addition, this principle is implemented in various individual agreements and contracts. These documents provide estimates of service effectiveness and employee encouragement tools. Among encouragement factors, there is the direct dependence of the rate of remuneration on the achievements of professional performance. The only exception is the senior management: their salary level is set individually, taking into account the degree of responsibility, the assessment of the unit's performance, professional experience, and qualifications.

In 2011-2012, during the country's economic downturn and freezing of salary increases for UK public sector officials, Tom Winsor, Chief Inspector General of Her Majesty in Police Affairs, conducted an independent analysis of issues related to the remuneration of police officers to reform it. The two reports, published in 2011-2012, highlighted and assessed the real needs of the modern British police in relation to the economic realities of the country and problems of aging population (Official website of the UK Government).

The main recommendations consisted of the following provisions:

- to reduce the salaries of employees who start a police career and have no work experience (that is, lowering the so-called "starting salary"). The purpose was the need to encourage long-term police service;

- to consider the level of salaries of police officers in connection with certain professional skills, paying supplementary payment to officers, who use these skills in their professional activities (equated to $£ 600$ ). To do this, special skills, which a police officer should possess and for which an additional payment should be paid, were suggested to be listed. The purpose of this measure was the development of employees' professional knowledge, raising the level of qualification to use the potential in full, as well as changing the public opinion about the level of professionalism of the police;

- to consider salaries in close relation with professional performance, increasing remuneration only to those employees who, on the basis of the calendar year results, performed a job satisfactorily or better;

- to conduct the so-called "fitness testing" regularly to make sure that all employees are in good physical shape, because a badly trained worker endangers himself, his colleagues, and society. The reports were suggested to make an exception for employees who were injured during the period of service and to grant them a delay of one year for testing, as well as an opportunity to improve their health. Officials who would not be able to pass the test for the second time should be dismissed from the police with the payment of retirement benefits and a lifetime premium pension;

- to appoint employees, who have a certain level of qualifications, appropriate work experience and a certain level of education, for the position of police officers;

- to introduce a mandatory weekend system for police officers; to involve in overtime work only certain categories of employees in exceptional cases, paying compensation for overtime work;

- to increase the retirement age to 60 years.

The Ministry of Internal Affairs of Great Britain took most of Winsor's recommendations, given in the reports. Moreover, as a result of the reform, the rate of police officer salaries has increased (with the exception of certain categories) compared to other public officials and employees of other sectors and employees will still be retired earlier than other state employees and receive a higher pension in comparison with other categories of pensioners.

However, following the ratification of the recommendations contained in the two W. Winsor's reports on salaries by the Minister of the Internal Affairs of Great Britain, salaries of certain categories of police officers were reduced. Mostly, this has affected employees, newly recruited to the police, and employees with low seniority. For example, since April 1, 2013, constable salaries have been reduced:

- from $£ 23259$ to $£ 19000$ for newly recruited employees; - from $£ 25962$ to $£ 21000$ for constables with low seniority (Policeoracle).

In Ukraine, encouraging employees according to the professional performance enables to solve problems connected with the increase of efficiency of the law-enforcement system. Therefore, nowadays the development of clear criteria for assessing the professional performance of law enforcement officials, 
the creation of an effective system of material incentives based on professional performance, are a priority task.

At present, the rate, conditions, and procedure for the appointment of encouraging payments are not aimed at improving the effectiveness of the law enforcement service.

For example, the legislation specifies that the heads of the police have the right to award police officers in accordance with the specificities of the service and personal contribution of a policeman to general professional performance of the service, considering the specifics and peculiarities of the performance of the tasks assigned to him/her and within the limits approved for remuneration for the maintenance of the National Police.

Therefore, in the course of further reform of the police, such as improving social policy, the issue of forming new principles and methodology for the encouragement of employees objectively considering their professional performance is of particular importance. The use of foreign experience in solving such problems can be a positive example for domestic public administration bodies in the implementation of social reforms in law enforcement structures.

On the one hand, using foreign experience, certain methods of problem-solving can be "copied" or mechanically transferred to Ukrainian realities. On the other, it should be considered that some aspects of reform are of a universal nature, while others can only be applied under certain conditions related to the political situation in the country, the level of development of the economy and social sphere, as well as the level of criminalization of society.

However, obviously, the system for assessing the efficiency and professional performance of law enforcement activities should have a hierarchical structure and be based on the level of strategic goals and objectives, requirements of society and the state to the police, to the level of specific tasks of units and individual employees. The efficiency of police activity depends on obtaining a certain remuneration (moral or material) for the good performance of one's authorities, as well as on the assessment of the activities of police officers both from colleagues and leadership and, to a large extent, from the public and the media (Kuba, Topoleskyi).

\section{Conclusions}

Therefore, it should be noted that the system of indicators should evaluate comprehensively the activities of employees, units, and the National Police System as a whole, include the full range of indicators necessary for evaluation, exclude duplicate or secondary indicators, consider the priority of the tasks performed, clearly reflect the degree of achievement at all levels of the system, and be based on potentials of budget financing. The system of supplementary payments must be based on a finite number of professional performance indicators. Moreover, it is important to meet such a criterion as objectivity, adequacy of types and rate of supplementary payments. In addition, fixing supplementary payments, based on performance efficiency indicators, should reflect the danger, importance for the state and society, and specificity of the tasks performed, as well as the priority exercised by the police. Furthermore, the number of indicators linked to supplementary payments should be optimal, otherwise, in case of an overly-specified system with a large number of indicators reflecting relatively small functions, there is a risk of diverting attention from solving key problems, as well as compensation for the decline in the quality of core duty performance by a large number of less significant functions.

\section{References:}

Jenkins C. (February 1999). Concerns raised over gap between funding and pay. Police review, 7.

Pro Natsionalnu politsiiu [On National Police] (Law of Ukraine of July 2, 2015). Retrieved from: http://zakon2.rada.gov.ua/laws/show/580-19 (in Ukrainian)

Pro pensiine zabezpechennia osib, zvilnenykh z viiskovoi sluzhby, ta deiakykh inshykh osib [On Pension Provision of Persons Released from Military Service and Some Other Persons] (Law of Ukraine of April 9, 1992). Retrieved from: http://zakon5.rada.gov.ua/laws/show/2262-12 (in Ukrainian)

Pro zatverdzhennia Polozhennia pro Natsionalnu politsiiu [On approval of the Regulation on the National Police] (Resolution of the Cabinet of Ministers of Ukraine no. 877 of October 28, 2015). Retrieved from: http://zakon3.rada.gov.ua/laws/show/877-2015-\%D0\%BF/paran9\#n9 (in Ukrainian)

Pro hroshove zabezpechennia politseyskykh Natsionalnoi politsii [On the remuneration of police officers of the National Police] (Resolution of the Cabinet of Ministers of Ukraine no. 988 of November 11, 2015). Retrieved from: https://www.kmu.gov.ua/ua/npas/248668490 (in Ukrainian)

Pro poriadok obchyslennia vysluhy rokiv, pryznachennia ta vyplaty pensii i hroshovoi dopomohy osobam ofitserskoho skladu, praporshchykam, michmanam, viiskovosluzhbovtsiam nadstrokovoi sluzhby ta viiskovoi sluzhby za kontraktom, osobam nachalnytskoho i riadovoho skladu orhaniv vnutrishnikh sprav, politseyskym ta chlenam yikhnikh simey [On the procedure for calculating the years of service, appointment and payment of pensions and remuneration to the commissioned officers, warrant officers, midshipmen, extended military servicemen and military service under the contract, persons of senior commanders and junior enlisted of the internal affairs bodies, police officers and their family members] (Resolution of the Cabinet of Ministers of Ukraine no. 393 of July 17, 1992). Retrieved from: http://zakon5.rada.gov.ua/laws/show/393-92-\%D0\%BF (in Ukrainian) 
Pro zatverdzhennia Poriadku ta umov vyplaty hroshvoho zabezpechennia politseyskym Natsionalnoi politsii ta kursantam vyshchykh navchalnykh zakladiv MVS iz spetsyfichnymy umovamy navchannia [On approval of the procedure and conditions for payment of remuneration to provide police officers of the National Police and cadets of higher educational institutions of the Ministry of Internal Affairs with specific learning conditions] (Order of the Ministry of Internal Affairs of Ukraine no. 260 of April 06, 2016). Retrieved from: http://zakon5.rada.gov.ua/ laws/show/z0669-16 (in Ukrainian)

Official website of the Royal Canadian Equestrian Police. Retrieved from: http://www.rcmp-grc.gc.ca/ recruitingrecrutement/rm-mr/rates-taux-eng.htm

Official website of the UK Government. Retrieved from: https://www.gov.uk/police-pay-winsor-review Policeoracle. Retrieved from: http://www.policeoracle.com/pay_-and_conditions/police_pay_scales.html

Kuba N., Topoleskyi R. Systema otsinky efektyvnosti roboty Natsionalnoi politsii [The system of assessing the effectiveness of the work of the National Police]. Retrieved from: http://khpg.org/index.php?id=1455530110 (in Ukrainian) 